\author{
MARTA ŁUCZAK \\ Collegium Civitas \\ $w$ Warszawie
}

\title{
MOBILNOŚĆ EDUKACYJNA JAKO PUNKT ZWROTNY W BIOGRAFII JEDNOSTKI
}

\begin{abstract}
Marta, Mobilność edukacyjna jako punkt zwrotny w biografii jednostki [Educational Mobility as a Turning Point in the Personal Biography]. Studia Edukacyjne nr 41, 2016, Poznań 2016, pp. 289-306. Adam Mickiewicz University Press. ISSN 1233-6688. DOI: 10.14746/se.2016.41.18

The increasing number of migrations is the main quality of modern society. Formerly, migration was a single action of leaving one's country of origin, aimed at settling in a new place. Nowadays, migration should be described as a mobility that is a repeated change of the country of residence and a temporary stay in a new place. The status of mobility has a huge influence on modifying personal identity through the experience of life in different cultures. The article indicates the reasons for educational mobility and its consequences for personal biography. The change of self-definitions influences the further personal process of life.
\end{abstract}

Key words: educational mobility, biography, identity

\section{Mobilność jako szczególny typ migracji}

Współczesne społeczeństwo charakteryzuje się wrastającą liczbą migracji. W przeciwieństwie do dawnych migracji, kiedy była ona aktem jednorazowym i polegała na opuszczaniu kraju pochodzenia w celu osiedlenia się w nowym miejscu, obecnie jest złożonym układem powiązań, znacznie różniącym się od tradycyjnego modelu dwubiegunowego ${ }^{1}$.

1 E. Budakowska, Wspótczesne migracje a nowe wyzwania wobec identyfikacji narodowokulturowej, [w:] Tożsamość bez granic. Wspótczesne wyzwania, red. E. Budakowska, Warszawa 2005, s. 56. 
Romaniszyn pisząc o współczesnych migracjach, wskazuje na niewykształconych mieszkańców ubogiego Południa - peryferii, którzy zmierzają do bogatych krajów - Centrum w celu znalezienia pracy². Podobnie jak $\mathrm{w}$ przeszłości ubodzy, niewykształceni chłopi wędrowali do miast w celu znalezienia zatrudnienia jako robotnicy $\mathrm{w}$ rozwijającym się sektorze przemysłowym, tak osoby o niskich kwalifikacjach podejmą $\mathrm{w}$ metropoliach niskopłatne prace. Kierunek tych migracji uległ jednak zmianie. W przeszłości to przede wszystkim Europejczycy wyruszali w drogę do Stanów Zjednoczonych lub do kolonii państwa swojego pochodzenia. Obecnie to Europa staje się miejscem docelowym dla przybyszów z innych kontynentów. Trudno jednak jednoznacznie wskazać, które kraje są krajami emigracji, a które imigracji. Migracje obejmują bowiem nie tylko kierunek „PeryferieCentrum", ale cały świat. Typowe miejsca emigracji oraz imigracji ulegają wymieszaniu. Dychotomiczny podział na państwa wysyłające i państwa przyjmujące zanikł3. Ponadto, przemieszczają się de facto nie tylko ubodzy mieszkańcy z krajów Południa, ale przepływ osób odbywa się także pomiędzy bogatymi krajami ${ }^{4}$. Wiąże się to między innymi z wymianą pracowników zatrudnionych w korporacjach międzynarodowych, którzy przemieszczają się pomiędzy siedzibami swojej firmy. Taka cyrkulacyjna migracja wysokiej klasy specjalistów ma pobudzić rozwój przedsiębiorstw, jednak dla pojedynczych państw nie zawsze oznacza to rozwój gospodarczy. Castles i Miller zwracają uwagę, że ubogie kraje mogą zostać pozbawione personelu niezbędnego do zapewnienia podstawowych usług, które wpłynęłyby na ich rozwój, gdyż osoby posiadające kwalifikacje w zakresie zarządzania, inżynierii, technik informatycznych, edukacji i praktyki medycznej są zachęcane przez bogatsze państwa do wyjazdu ${ }^{5}$. W krajach wysokorozwiniętych napływ pracowników o wysokich kwalifikacjach jest jednym z głównych aspektów polityki imigracyjnej6. Państwa, jak i przedsiębiorstwa rywalizują między sobą o najlepszych pracowników, ponieważ zdają sobie sprawę, że są oni najważniejszym ogniwem w budowaniu innowacyjnej i konkurencyjnej gospodarki.

Przykład sektora, w którym przepływ pracowników jest bardzo wysoki stanowi branża informatyczna. Językiem komunikacji jest język angielski, ułatwiający podejmowanie pracy $\mathrm{w}$ innych krajach i swobodne przemiesz-

\footnotetext{
2 K. Romaniszyn, Kulturowe implikacje międzynarodowych migracji, Lublin 2003, s. 35.

${ }^{3}$ S. Castles, M.J. Miller, Migracje we wspótczesnym świecie, Warszawa 2011, s. 24.

4 Tamże, s. 20-21.

5 Tamże, s. 89.

${ }^{6}$ P. Kaczmarczyk, M. Okólski, Migracje specjalistów wysokiej klasy w kontekście członkostwa Polski w Unii Europejskiej, Warszawa 2005, s. 53.
} 
czanie. Ponadto, najważniejszym wyznacznikiem kwalifikacji zawodowych w tym sektorze nie jest dyplom wyższej uczelni, ale doświadczenie i umiejętności, niekoniecznie nabyte $\mathrm{w}$ drodze edukacji formalnej. Praca $\mathrm{w}$ nim jest niezależna od kontekstu kulturowego, ponieważ nowoczesne technologie mają wymiar kultury globalnej

W przeszłości zjawisko odpływu pracowników wysoko wykwalifikowanych występowało na masową skalę $\mathrm{w}$ pierwszej połowie $X X$ wieku. Wiązało się to jednak głównie z sytuacją polityczną na świecie. Z kolei, $\mathrm{w}$ okresie powojennym czynnikiem pobudzającym migracje specjalistów był dynamiczny rozwój sektora obronnego i przemysłów towarzyszących ${ }^{8}$. W przeszłości migracja $\mathrm{w}$ celu podjęcia pracy dotyczyła przede wszystkim osób bez kwalifikacji, które nie mogły znaleźć pracy w kraju pochodzenia. Obecnie migracja osób z wysokimi kwalifikacjami jest powszechna i służy realizacji ich wysokich aspiracji. Stanowi zaplanowane działanie służące realizacji ich planów zawodowych. Specjaliści międzynarodowi nie pochodzą z regionów o wysokiej skali bezrobocia i nie decydują się na emigrację z powodu braku pracy. Przyczyną ich mobilności nie są też większe zarobki, ale przede wszystkim możliwość rozwoju zawodowego i osobistego oraz dostęp do najnowszych technologii. Grupa ta nie ucieka przed bezrobociem $\mathrm{w}$ kraju pochodzenia, ale $\mathrm{z}$ wyprzedzeniem planuje swoje cele zawodowe i przyszłe miejsce pracy. Ten typ mobilności nie wiąże się zatem ze zdeklasyfikowaniem tak, jak ma to zazwyczaj miejsce w przypadku typowych emigrantów zarobkowych, ponieważ podejmują pracę na stanowisku równorzędnym lub wyższym. Konsekwencją globalizacji rynku pracy, a jednocześnie przyczyną wzrostu mobilności jest stopniowe ujednolicanie szkolnictwa wyższego, które ma na celu ujednolicenie systemu nadawania dyplomów potwierdzających wykształcenie i kwalifikacje zawodowe.

Migracje współczesne są więc zróżnicowane pod względem płci, wieku, statusu społecznego, wykształcenia i wykonywanego zawodu. Różne typy migracji występują równocześnie w tym samym miejscu i czasie, przekształcając się $\mathrm{z}$ jednych $\mathrm{w}$ drugie. Takie zróżnicowanie stanowi trudność $\mathrm{w}$ wypracowaniu lokalnych i międzynarodowych strategii politycznych wobec imigrantów ${ }^{9}$. Migracje oddziałują na stosunki dwustronne i regionalne między krajami, a w skali światowej na politykę bezpieczeństwa narodowego. Wskazuje się, że przemieszczanie się ludzi w tak dużej skali niesie ze sobą zagrożenie dla suwerenności państw, głównie w kwestii jego zdolności do

\footnotetext{
7 Tamże, s. 55.

8 Tamże, s. 51-52.

${ }^{9}$ S. Castles, M.J. Miller, Migracje, s. 28-29.
} 
regulowania przepływu ludzi przez granice. Jednocześnie, stosunek państw przyjmujących wobec przybyszów ulega zmianie. W przeszłości rządy narodowe wprowadzały utrudnienia dla emigrantów, dążąc do asymilacji przyjezdnych. Począwszy od 70. lat XX wieku państwa zaczęły stopniowo prowadzić tzw. politykę wielokulturowości, polegającą na przyznaniu społecznościom imigranckim praw kulturalnych i politycznych. Kolejna zmiana kierunku działań nastąpiła po 11 września 2001 roku. Osiedlanie się imigrantów zaczęło być postrzegane jako zagrożenie dla tożsamości państw narodowych ${ }^{10}$, gdyż $\mathrm{w}$ wyniku migracji powstaje społeczeństwo pozbawione wspólnego etnicznego rodowodu i wspólnej kultury ${ }^{11}$. Zdaniem Romaniszyn, migracje są czynnikiem zmian kulturowych prowadzących do pogłębienia zróżnicowania kulturowego ${ }^{12}$, co w konsekwencji powoduje

odrodzenie rasizmu wśród gospodarzy i pojawienie się fundamentalizmu wśród pewnych imigranckich grup etnicznych, co grozi zderzeniem cywilizacji w obrębie tychże społeczeństw ${ }^{13}$.

Trudno jednak zgodzić się z tezą, że każda dyfuzja odmiennych wartości oznacza „wojnę kultur” i nasilenie się fundamentalizmu. Powszechność migracji i prawdopodobieństwo, że każdy z nas może stać się emigrantem powoduje bowiem zmianę $\mathrm{w}$ stosunku do osób przyjezdnych. Ponadto, emigranci nie zawsze tworzą getta pozostając $w$ kręgu oddziaływań grupy swojego pochodzenia, ale część $\mathrm{z}$ nich podejmuje działania zmierzające do pokojowego współżycia ze społecznością przyjmującą. Coraz bardziej powszechna staje się także integracja z międzynarodową społecznością emigrancką. Wzrastająca liczba miast i krajów wielokulturowych powoduje, że powstają tam wielokulturowe społeczności imigranckie, zwane też społecznościami transnarodowymi ${ }^{14}$. Jej członkowie charakteryzują się podwójną lub wieloraką identyfikacją narodową. Przenikanie i mieszanie się zjawisk kulturowych prowadzi z kolei do zaistnienia zjawiska hybrydyzacji kulturowej $^{15}$ i pluralizmu, co z kolei przyczynia się do obniżenia nacisku społecznego na asymilację migrantów ${ }^{16}$. W związku z tym, pomimo pojawiającej się od czasu do czasu negatywnej retoryki państw w stosunku do zjawiska imi-

\footnotetext{
10 Tamże, s. 32.

11 Tamże, s. 33.

12 K. Romaniszyn, Kulturowe implikacje, s. 10.

13 Tamże, s. 149.

14 D. Niedźwiedzki, Migracje i tożsamość. Od teorii do analizy przypadku, Kraków 2010, s. 34-35.

15 A. Grzymała-Kazłowska, Ku socjologii mobilnego społeczeństwa? Rozwój nowych koncepcji migracji i integracji a socjologia, Studia Socjologiczne, 2013, 3(210), s. 35.

${ }_{16}$ D. Niedźwiedzki, Migracje i tożsamość, s. 34-35.
} 
gracji i praktyk dyskryminacji wobec osób przyjezdnych, powszechnie jednak państwa tworzą politykę integracyjną, która stawia kulturę i dziedzictwo osób przyjezdnych na równym poziomie z kulturą społeczeństwa przyjmującego. Imigrant ma możliwość zachowania swoich tradycji, religii, zwyczajów, a wszelkie przejawy nietolerancji lub rasizmu są społecznie napiętnowane ${ }^{17}$. W konsekwencji może to prowadzić do "akulturacji bez asymilacji". Oznacza to, zdaniem Babińskiego, że imigranci poznają i postępują zgodnie kulturą kraju pobytu, ale nie uznają jej za swojej. Wprawdzie nie jest to zjawisko nowe, ale obecnie jest to postawa coraz częściej przyjmowana przez imigrantów ${ }^{18}$.

Z drugiej strony, rządy państw stoją przed problemem lojalności swoich własnych obywateli, którzy emigrują. Przemieszczając się, budują oni bowiem więzi polityczne, ekonomiczne, społeczne i kulturowe z dwoma lub kilkoma państwami i społeczeństwami jednocześnie. $W$ ten sposób naruszona zostaje dotychczas niepodzielna lojalność uznawana za element suwerenności państw narodowych ${ }^{19}$. Państwa pochodzenia pozostają jednak ciągle ważne dla osób wyjeżdżających, głównie dzięki temu, że obecnie osoby migrujące wyjeżdżając z kraju pochodzenia mają ukształtowaną identyfikację narodową. Zwraca na to uwagę Babiński badając sytuację Polaków w USA. W przeszłości identyfikacja z Polską kształtowała się wyraźniej dopiero w momencie wyjazdu - za granicą "stawali się tam Polakami", łącząc swoją dopiero co uświadomioną identyfikację narodową z identyfikacją z krajem pobytu. Współcześni migranci zachowują więź z krajem pochodzenia dzięki polityce państw przyjmujących, ułatwiającej utrzymanie odrębności kulturowej, a także poprzez rozwój form przekazu, transportu i komunikacji ${ }^{20}$. Emigranci nie są obecni w swoich społecznościach w sensie fizycznym, ale dzięki „obecności on-line” mogą komunikować się i nadal uczestniczyć w życiu lokalnej społeczności ${ }^{21}$. W ten sposób emigranci, mimo braku geograficznej bliskości, ciągle uważają się za członków wspólnoty, z której pochodzą22.

Ponadto, pobyt $\mathrm{w}$ innym miejscu może być ograniczony w czasie, a powroty do kraju pochodzenia są wielokrotne. Współczesne migracje charakteryzuje bowiem niestałość. W przeszłości migracja oznaczała wyjazd zazwy-

${ }^{17}$ J. Urry, Socjologia mobilności, Warszawa 2009, s. 239-240.

${ }_{18}$ G. Babiński, Polonia w USA na tle przemian amerykańskiej etniczności, Kraków 2009.

${ }^{19}$ S. Castles, M.J. Miller, Migracje, s. 19-20.

${ }^{20}$ G. Babiński, Polonia w USA.

21 A. Appadurai, Nowoczesność bez granic. Kulturowe wymiary globalizacji, Kraków 2005, s. 203-295.

22 J. Urry, Socjologia mobilności, s. 107-108. 
czaj w jedną stronę, bez możliwości powrotu do kraju pochodzenia. Obecnie przemieszczanie pomiędzy krajami jest łatwiejsze, dzięki szybszemu, dogodniejszemu i tańszemu podróżowaniu. Migracja nie musi oznaczać jednorazowego wyjazdu ze swojego miejsca zamieszkania w celu osiedlenia się w innym kraju, ale może łączyć się z wielokrotną i częstą zmianą miejsca pobytu, która nie jest ukierunkowana na pozostanie $\mathrm{w}$ innym miejscu przez dłuższy okres. Ten drugi typ migracji proponuję nazwać mobilnością. Mobilność jest takim typem migracji geograficznej, która łączy się z wielokrotną zmianą miejsca pobytu w sensie fizycznym. Jednostki doświadczające mobilności nie przemieszczają się jedynie z kraju pochodzenia do nowego kraju pobytu, ale kontynuują podróż do kolejnych krajów, nie ograniczając się jedynie do jednego kontynentu. Mobilność może więc przebiegać we wszystkich kierunkach, łącznie z powrotami do wcześniejszych miejsc pobytu. Może wiązać się z krótkotrwałym pobytem w różnych miejscach, oddzielonym lub nie krótkotrwałym pobytem w kraju w pochodzenia.

Mobilność, jak każda migracja, wiąże się z doświadczeniem życia $\mathrm{w}$ innej kulturze, co łączy się z pytaniami o własną tożsamość. Wielokrotna zmiana miejsca pobytu powoduje jednak, że jednostka nie jednorazowo, ale kilkakrotnie musi uporządkowywać swój stosunek do grup i kultur krajów pobytu oraz grupy i kultury kraju pochodzenia. Zbierając zatem doświadczenie życia $\mathrm{w}$ kilku miejscach, mobilna jednostka weryfikuje autodefinicje w odniesieniu do każdego wcześniejszego i późniejszego miejsca swojego pobytu. Pytanie o przebieg i sposób modyfikacji tożsamości jednostki stało się głównym pytaniem moich badań.

\section{Mobilność edukacyjna wśród polskich studentów}

Wybraną przeze mnie grupą badawczą byli Polacy studiujący na zagranicznych uniwersytetach. Uczestnicy badań odbywali studia licencjackie, magisterskie lub doktoranckie na uczelni za granicą. Respondenci byli związani m.in. z Uniwersytetem w Oksfordzie, szkockim uniwersytetem Saint Andrews, londyńskimi uczelniami i ośrodkami badawczymi, Uniwersytetem $\mathrm{w}$ Reading oraz Środkowoeuropejskim Uniwersytetem w Budapeszcie. Należy jednak zaznaczyć, że część uczestników badań była wcześniej uczniami szkół średnich za granicą lub mieli już za sobą pobyt jako studenci na innych uniwersytetach $w$ tym samym kraju lub w innych krajach, np. w Holandii, Hiszpanii, Stanach Zjednoczonych. Wywiady zostały przeze mnie przeprowadzone od czerwca 2012 do stycznia 2013 roku. Łącznie 
przeprowadziłam 14 wywiadów (3 wywiady odbyły się w Oksfordzie, $6 \mathrm{w}$ Londynie, $1 \mathrm{w}$ Monachium, $4 \mathrm{w}$ Polsce). Ze względu na mobilny styl życia studentów, nie zawsze odbywały się one w miastach, gdzie znajdował się uniwersytet, na którym obecnie studiowali. Badania były prowadzone w miejscach, gdzie akurat przebywali i dysponowali czasem, by wziąć udział w wywiadzie.

Najwięcej wywiadów przeprowadziłam z osobami studiującymi w Wielkiej Brytanii. Polska społeczność imigrancka w tym kraju, jak i liczba polskich studentów jest bardzo duża; w roku akademickim 2010/2011 studiowało tam 7730 Polaków, a w 2011/2012 - 6 29523. Dla porównania z danymi UNESCO, w roku akademickim 2007/2008 za granicą studiowało około 32 tysiące Polaków. Najwięcej w Niemczech (ok. 10 800), Wielkiej Brytanii (8 600), Francji (3 260 osób), USA (ponad 2 730), Austrii (ponad 1 630) i Włoszech $(1480)^{24}$. Polscy studenci wybierają Wielką Brytanię przede wszystkim z braku bariery językowej. Powszechna znajomość języka angielskiego powoduje, że młodzi ludzie mogą bez ograniczeń uczestniczyć w zajęciach oferowanych przez uniwersytet. Należy jednak pamiętać, że coraz większa liczba uniwersytetów w Europie oferuje kursy w języku angielskim. Dzięki temu zostaje zlikwidowana bariera językowa dla studentów nie posługujących się językiem kraju przyjmującego. Z takiej możliwości korzystały także niektóre osoby biorące udział $\mathrm{w}$ moich badaniach. Nie zmienia to jednak faktu, że studia w Wielkiej Brytanii oznaczają znajomość języka kraju przyjmującego, co pozwala na nawiązywanie kontaktu z członkami społeczności lokalnej. Ponadto, Wielka Brytania, w porównaniu z innymi krajami anglojęzycznymi, jest bardziej popularna wśród polskich studentów głównie dzięki zniesieniu ograniczeń związanych z wjazdem i pobytem, co wynika z członkostwa obu krajów w Unii Europejskiej i swobodzie przemieszczenia się.

\section{Mobilność edukacyjna jako punkt zwrotny w biografii jednostki}

Każdy przeprowadzony przeze mnie wywiad rozpoczynał się od pytania dotyczącego przyczyn wyjazdu za granicę. W tej części wywiadu respondenci mówiąc o własnych doświadczeniach, przekazywali zazwyczaj

${ }^{23}$ UK Council for International Student Affairs (UKCISA), http://www.ukcisa.org.uk/ about/statistics_he.php, [dostep:9.04.2013].

${ }^{24}$ Ośrodek Badań nad Migracjami, „Biuletyn Migracyjny”, 2010, 26, s. 8, http://biuletyn migracyjny.uw.edu.pl/pliki/pdf/biuletynmigracyjny26.pdf , [dostęp: 9.04.2013]. 
szczegółową relację zdarzeń związanych z tym etapem w ich życiu. Dzięki temu było możliwe zrekonstruowanie indywidualnej biografii oraz ustalenie stosunku respondenta do minionych wydarzeń. Respondent opowiadał o zdarzeniach i prezentował powiązania pomiędzy nimi, a także oceniał i komentował przeszłe wydarzenia ze swego dzisiejszego punktu widzenia ${ }^{25}$. Ta część wywiadu zawierała elementy wywiadu narracyjnego, co pozwoliło mi na zanalizowanie zjawisk związanych $z$ wyjazdem $w$ ujęciu biograficznym. Przyjecie tej perspektywy oznacza rozpatrywanie decyzji o wyjeździe jako procesu, na który składało się zazwyczaj kilka czynników rozłożonych w czasie. Ponadto, dzięki takiemu ujęciu losy jednostek mogą być porównane i zanalizowane w kontekście procesów społecznych związanych ze zmianami dotyczącymi zjawisk migracyjnych.

Doświadczenia biograficzne jednostek są wytwarzane lub interpretowane $\mathrm{w}$ interakcjach. Podczas wywiadu jednostka analizuje zdarzenia $\mathrm{z}$ własnej przeszłości, ponownie je interpretując i zmieniając do nich swój stosunek. Tym samym zmienia także stosunek do samego siebie i znaczących innych ${ }^{26}$. Decyzja o wyjeździe była zatem analizowana przez respondenta z obecnej perspektywy, uwzględniającej nabyte doświadczenia za granicą. W ten sposób opisywane zdarzenia częściowo odnoszą się do przeszłości, a częściowo do teraźniejszości, zachowując tym samym ciągłość doświadczenia biograficznego.

Schütze wyróżnił struktury procesowe biografii odpowiadające odmianom stosunku narratora biografii do istotnych faz jego życia oraz formom jego działań społecznych - działań intencjonalnych oraz działań uwarunkowanych i sterowanych zewnętrznie. Jedną ze wskazanych przez Schütze struktur, a odpowiadającą zebranym przeze mnie narracjom dotyczących wyjazdu z Polski, są biograficzne plany działania. Uczestnicy moich badań perspektywicznie planowali przebieg własnego życia oraz podejmowali działania na rzecz realizacji swoich zamierzeń. Ten biograficzny schemat działania jest intencjonalnym działaniem jednostki. Inną formą realizacji struktury procesowej opisanej przez Schütze i odpowiadający działaniom respondentów jest zamiar spróbowania czegoś nowego. Jest on spowodowany impulsem, bez wyraźnie sprecyzowanego celu, który z perspektywy czasu okaże się biograficznie doniosły. Innym wariantem jest chęć dokonania zmiany. Jednostka może czuć się ograniczona przez swój dotychczasowy

25 A. Rokuszewska-Pawełek, Chaos i przymus. Trajektorie wojenne Polaków - analiza biograficzna, Łódź 2002, s. 56.

${ }^{26}$ G. Reimann, F. Schütze, "Trajektoria” jako podstawowa koncepcja teoretyczna w analizach cierpienia i bezładnych procesów społecznych, Kultura i Społeczeństwo, 1992, 2, XXXVI, s. 94. 
tryb życia i podejmuje czynności wykraczające poza rutynowe sposoby rozwiązywania problemów ${ }^{27}$.

Przyjęcie perspektywy biograficznej do analizy czynników kierujących decyzją o wyjeździe pozwala także spojrzeć na sam moment wyjazdu jako punkt zwrotny będący przejściem $\mathrm{z}$ fazy życia $\mathrm{w}$ kraju pochodzenia do mobilnego etapu życia. Strauss uznaje takie punkty zwrotne za kluczowe $\mathrm{w}$ procesie modyfikacji tożsamości. Jednostka pod wpływem wydarzeń biograficznych i związanych $\mathrm{z}$ nimi relacji społecznych dokonuje zmiany $\mathrm{w}$ autodefinicji. Punkty zwrotne oznaczają krytyczne wydarzenia, które są związane załamaniem lub zahamowaniem dotychczasowego planu działania. Powodują one, że w autorefleksji jednostki pojawia się poczucie istotnej zmiany, przekonanie, że nie jest ona już tym, kim była dotychczas. Sytuacją tworzącą punkt zwrotny jest np. sytuacja sprostania wyzwaniu - związana $\mathrm{z}$ procedurą testowania jednostki przez samą siebie $\mathrm{w}$ celu potwierdzenia zmiany poprzednich statusów i atrybutów oraz trwałości nowo nabytych. Spotkanie z przedstawicielami innych kultur lub przebywanie w społeczności studentów międzynarodowych jest tego rodzaju wyzwaniem, gdyż status jednostki i jej miejsce w nowym środowisku wymaga dopiero ukształtowania. Ponadto, sytuacja wyjazdu powoduje zmianę "ważnych innych", którzy wpływają na jednostkę i przyjmowane przez nią autodefinicje.

\section{Przyczyny decyzji o wyjeździe}

Moi rozmówcy wyjechali z Polski posiadając już zazwyczaj status studenta, czyli już po zaakceptowaniu ich aplikacji przez uniwersytet za granicą. Był to więc wyjazd w celu realizacji konkretnego zadania. Jedynie trójka respondentów podjęła studia już podczas pobytu i wcześniejszym doświadczeniu pracy w innym kraju. Wszystkie osoby udzielające wywiadu podjęły decyzję o wyjeździe w sposób dobrowolny i nie były do niego przymuszone żadnymi okolicznościami zewnętrznymi. Świadczy o tym nie tylko ich deklaracja i opowiedziana przez nich historia życia $\mathrm{w}$ tym etapie, ale także sposób w jaki określają swój wyjazd. Monika nazywa go „ryzykiem”, Grzegorz „wyzwaniem”, a Jerzy mówi o "przygodzie” (,zasmakować takiej przygody za granica", Jerzy).

Analizując zebrany materiał, wyodrębniłam kilka powodów wyjazdu, opierających się na grupie dominujących czynników wypychających z kraju

27 A. Rokuszewska-Pawełek, Chaos i przymus, s. 45-50; K. Kaźmierska, Wywiad narracyjny jako jedna z metod w badaniach biograficznych, Przegląd Socjologiczny, 2004, LIII/1, s. 84-86. 
pochodzenia (push) i przyciągających do innych miejsc (pull). W przypadku osób mobilnych należy bowiem zawsze operować szerszą przestrzenią, nie ograniczoną tylko do jednego kraju wyjazdu.

Pierwszym, najważniejszym i najczęstszym powodem wyjazdu była po prostu chęć odbycia studiów na zagranicznym uniwersytecie. Część respondentów wyjechała zaraz po ukończeniu szkoły średniej i zdaniu matury. Osoby te wcześniej nie studiowały na polskich uczelniach wyższych. Inni respondenci wyjechali już po rozpoczęciu nauki na uniwersytecie $w$ Polsce lub po ukończeniu I lub II stopnia studiów. Studia za granicą uznali za lepszy wybór, przede wszystkim ze względu na ich jakość i możliwość nauki na uczelni wysoko usytuowanej $\mathrm{w}$ rankingu najlepszych uniwersytetów na świecie. Łączyło się to bowiem $\mathrm{z}$ ich wysokimi aspiracjami edukacyjnozawodowymi. Mówi o tym na przykład Monika: „(...) jeżeli jest jakość, jest różnica w jakości, no to mi się wydaje, że warto podjać to ryzyko, no bo to jest ryzyko, no bo wszystko jest okupione jakimś tam kosztem, tak więc warto, moim zdaniem, warto się w to zabawić, no bo chodzi o edukacje, no i uczenie się po angielsku też moim zdaniem".

Dla osób, które studiowały wcześniej w Polsce, czynnikiem wypychającym było niezadowolenie z nauki na uczelni w swoim kraju. Na przykład dla Maćka był to najważniejszy powód wyjazdu. Maciek w ten sposób opisuje swoje studia doktoranckie w kraju pochodzenia: „(...) studia w Polsce (...) pomyłka, wielkie rozczarowanie przeżyłem, jak zacząem doktorat studiować (...) pierwszy rok (...) to było tak, że po pierwsze niczego się nie nauczyłem, niczego nowego (...) to znaczy trochę wiedziałem, że tak będzie, obstawiałem, bo już wtedy stwierdziłem, że raczej dtugo sobie nie posiedzę". Rozpoczęte studia doktoranckie w Polsce nazywa "pomyłka” i „wielkim rozczarowaniem”. Twierdzi, że na pierwszym roku niczego nowego się nie nauczył. Wówczas stwierdził, że lepiej zmienić uczelnię. Podobne doświadczenia mieli Jagoda i Łukasz, którzy zdecydowali się na wyjazd po pierwszym roku studiów. Wysoką jakość studiów za granicą uznali za jedyny sposób uniknięcia kolejnych rozczarowań (Łukasz).

Takich negatywnych doświadczeń chciał uniknąć Piotrek, który nigdy nie studiował na uniwersytecie $w$ Polsce, jednak jako laureat olimpiady podczas rekrutacji na studia $\mathrm{w}$ kraju pochodzenia spotkał się ze sporymi problemami związanymi z przyjęciem jego aplikacji. To krótkie doświadczenie związane z funkcjonowaniem administracji na polskiej uczelni spowodowało, że wybrał uniwersytet zagraniczny. Poszukując informacji o studiach na uniwersytecie w Anglii, spotkał się z życzliwym podejściem do kandydatów. Pierwsze wrażenia wyniesione z kontaktu z pracownikami 
biura rekrutacji okazały się głównymi czynnikami, które bezpośrednio zadecydowały o wyborze uniwersytetu: „(...) przypomniałem sobie te wszystkie problemy $z$ dziekanatem tam, a stąd $z$ kolei dostałem foldery mówiace, jaka to jest świetna uczelnia, jaka będę miat świetlana przyszłość (...). Muszę powiedzieć, że jak miałem porównanie między tymi dwoma uniwersytetami, to jakby naturalnym wyborem było, wydawało się, że to będzie fajniejsza uczelnia" (Piotrek).

Bardzo istotne i często podkreślane przez respondentów było także pragnienie kontynuowania naukowego rozwoju i lepszych perspektyw dla przyszłej pracy zawodowej, możliwość zmiany i wykorzystania życiowej szansy, a także ciekawość świata i chęć podróżowania. Moi rozmówcy twierdzili, że studia na renomowanej uczelni dają lepsze możliwości pracy po studiach. Na przykład Julia, która ukończyła studia licencjackie w Polsce, uznała, że ukończenie studiów zagranicznych będzie jej atutem podczas aplikowania o pracę w Polsce: „(...) stwierdziłam, że muszę zrobić coś nowego, coś dodatkowego, coś innego, coś co wydawato mi się wtedy bardziej ambitne, nie powiem nadzwyczajne, ale po prostu coś, czym będe mogła się wyróżnić na rynku pracy, to był główny powód". Respondentka uznała, że dyplom zagranicznej uczelni będzie czymś "nowym", "dodatkowym", "bardziej ambitnym", a tym samym "wyróżni ją na rynku pracy". Julia nazywa swoją decyzję "inwestycja" i dopiero w przyszłości okaże się, czy była to decyzja właściwa.

Wśród innych powodów wyjazdu moi rozmówcy wymienili także szansę usamodzielnienia się od rodziców i życia poza domem. Uczestnicy badań wskazywali także na kulturowo-krajoznawczy aspekt wyjazdu. Na przykład, marzeniem Jerzego, jako absolwenta studiów licencjackich z zakresu filologii angielskiej, był wyjazd do kraju anglojęzycznego, gdzie mógłby poszerzyć wiedzę o kulturze: „(...) ja marzyłem o tym, żeby wyjechać tutaj do Anglii po prostu albo innego kraju angielskojezycznego, gdzie po prostu te wiedze o kulturze bym poszerzyt". Z kolei Grzegorz zdecydował się na wybór Wielkiej Brytanii, aby poznać i zwiedzić ten kraj: „(...) pomyślałem o Wielkiej Brytanii. Podobała mi się brytyjska kultura i nie ukrywam, że też pomyślatem o studiach ze względów turystycznych trochę, że mieszkanie w tej kulturze pozwoli mi zwiedzić więcej i zobaczyć więcej, postanowitem tam pojechać".

Jedynie dwóch rozmówców wspomniało o ekonomicznych powodach emigracji. Mówili o niskim stypendium naukowym dla doktorantów w Polsce (Maciek) oraz o perspektywie pracy w polskiej szkole "za marne grosze" (Jerzy). Żaden z nich nie wskazał jednak tego jako głównej przyczyny wyjazdu.

Co ciekawe, moi rozmówcy nie zawsze potrafili wyjaśnić powody swojego wyjazdu: "Zawsze chciatam wyjechać, no nie? Nie wiem skąd przyszedt mi 
ten pomyst, już teraz nie pamiętam” (Jagoda); "(...) tam po prostu coś mnie tutaj ciagnęło. Ja naprawdę nie potrafię tego wyttumaczyć" (Asia).

Czynnikiem wypychającym było niekiedy otoczenie społeczne. Postawa kosmopolityczna, która została przyjęta przez zdecydowaną większość moich rozmówców jest wynikiem procesów socjalizacyjnych - specyficznej atmosfery domu rodzinnego i doświadczeń migracyjnych członków rodziny, własnych doświadczeń związanych z odbytymi w przeszłości podróżami, oddziaływania kręgów społecznych złożonych z ludzi podróżujących i mających wysokie aspiracje edukacyjno-zawodowe. Doświadczenia migracyjne innych członków rodziny miały wpływ na przykład wówczas, gdy członkowie rodziny pochodzą lub mieszkają w innym kraju, jak w przypadku Jerzego i Bartka. "Ja mam pochodzenie angielskie, moje nazwisko nie jest polskie, mój pradziadek od strony taty byt Anglikiem” (Jerzy), „(...) duża czesść mojej rodziny to sa Anglicy i Amerykanie" (Bartek).

Dla niektórych osób wyjazd na studia do innego kraju nie był pierwszym długoterminowym wyjazdem w celach edukacyjnych za granicę. Niektórzy moi rozmówcy mieszkali już wcześniej w innych krajach i tam uczęszczali do szkoły. Wyjazdy te były spowodowane pracą rodziców. Na przykład, Grzegorz do liceum chodził w Stanach Zjednoczonych, a wcześniej przez kilka lat mieszkał w Szwajcarii i Belgii: „przez wiele lat mieszkałem w Szwajcarii, jeszcze w Belgii, pót życia spędziłem w Polsce". Podobnie Elżbieta, jako dziecko wyjechała $\mathrm{z}$ rodzicami do Włoch, następnie będąc jeszcze dzieckiem mieszkała w Tajlandii i Chinach. Szkołę średnią ukończyła w Polsce, ale po maturze naukę kontynuowała ponownie za granicą.

Inne osoby przed rozpoczęciem studiów na zagranicznym uniwersytecie miały już za sobą doświadczenie krótkotrwałego pobytu w innym kraju, na przykład poprzez europejski wolontariat (Ola), wyjazdy z zespołem tanecznym (Magda), pracę zarobkową w czasie wakacji (Asia), wymianę studentów na uniwersytecie (Maciek). Wydaje się, że wszystkie te wcześniejsze doświadczenia mobilności i spotkania z odmienną kulturą wpłynęły na decyzję o kolejnym, tym razem długoterminowym, wyjeździe. Wcześniejsze doświadczenia migracyjne umożliwiły im wejście w środowisko międzynarodowe, a studia pozwalają kontynuować życie w tym otoczeniu.

Podobną funkcję, jak wcześniejsze wyjazdy zagraniczne, pełniła szkoła średnia i zdawanie matury międzynarodowej (Monika, Jagoda, Ola). Osoby te $\mathrm{w}$ szkole średniej miały kontakt $\mathrm{z}$ absolwentami swojego liceum, którzy wyjechali na studia za granicę. Tak jak w przypadku osób, które wcześniej wyjeżdżały za granicę i dzięki temu zwróciły się w kierunku środowiska międzynarodowego, tak samo licealiści dzięki spotkaniom w szkole zaczęli 
przybliżać się do społeczności osób mobilnych. W ich sytuacji środowisko szkolne - rówieśnicy, absolwenci, nauczyciele - miało wpływ na ich decyzję o studiach za granicą. Ola mówi o "modzie na studiowanie za granica”: „Wyjechałam za granice, na studia (...) pod wptywem jakiejś takiej mody, która panowata u mnie w liceum". Monika wspominając czasy liceum mówi, że to właśnie otoczenie szkoły i spotkane tam osoby, które zamierzały bądź już wyjechały, miały wpływ na jej decyzję. I tak mówi o swoich doświadczeniach z liceum: „(...) jak już pojawitam się w tym kręgu ludzi, którzy myśla w ten sposób, no i którzy maja mature międzynarodowa, z pomysłem, że być może będę chciała pojechać, to się zaczęto samo kręcić". O swoim wejściu w środowisko międzynarodowe, dzięki szkole średniej, mówi również Jagoda: „(...) potem jak się zaczyna robić międzynarodowa mature $i$ iść tym systemem, gdzie nie ma zakuć - zdać - zapomnieć, to trudniej przejść na polski system z powrotem (...)". Studentka ta wskazuje inny system nauki w celu przygotowania się do matury międzynarodowej, który bardziej jej odpowiadał niż polski sposób nauczania.

Do grona osób, które miały wpływ na decyzję o wyjeździe należy także zaliczyć rodziców lub najbliższych przyjaciół. Na przykład, Anię do wyjazdu namówiła najbliższa przyjaciółka, które wychowywała się w Szkocji i chciała tam powrócić na studia. Dla Magdy osobą, która znacząco wpłynęła na wybór studiów za granicą, zamiast w Polsce, była jej mama - pracownik naukowy jednego $\mathrm{z}$ polskich uniwersytetów. Zachęciła ją, aby wybrany przez nią kierunek studiowała za granicą: „(...) moja mama wykłada psychologię na uniwersytecie i powiedziała, że jeżeli psychologia, to spróbuj za granica" (Magda). Również Monikę w decyzji o wyjeździe utwierdziła opinia rodziców na temat jakości edukacji na polskich uniwersytetach: „(...) zawsze jakoś tak w domu mówito się, że nie ma co studiować w Polsce, bo nasze uniwersytety, jak sie popatrzy w rankingu, to chyba najwyższy jest teraz w trzeciej czy czwartej setce, kiedy ja decydowatam się na studiowanie na uczelni znajdujacej się w pierwszej setce czy w pierwszej pięćdziesiątce, więc powiedzmy, że jest jakaś tam różnica jakości (Monika).

Wydaje się, że w przypadku młodych osób kluczowy w podjęciu decyzji o wyjeździe jest wpływ otoczenia i przebywanie wśród osób, które już wcześniej doświadczyły mobilności. Przekazywane wartości, zwłaszcza związane $\mathrm{z}$ karierą, spowodowały, że wejście $\mathrm{w}$ środowisko międzynarodowe postrzegają jako możliwe do osiągnięcia. Tym, co korzystnie wpływa na dążenie do realizacji ich planów jest także gotowość młodych ludzi do życia $\mathrm{w}$ środowisku zróżnicowanym kulturowo. Wyjazd wpisuje się $\mathrm{w}$ biografię tych osób jako punkt zwrotny, który wiąże się z procesem modyfikacji ich tożsamości. Niezależnie, czy wyjazd był zaplanowanym działaniem słu- 
żącym osiągnięciu konkretnych celów lub chęcią zmiany i sprostaniu wyzwaniom, respondenci zweryfikowali swoje autodefinicje. Podczas badań szczegółowo zanalizowałam ten proces poprzez ukazanie zmian $\mathrm{w}$ ich relacjach i poczuciu przynależności oraz znajomość i uczestnictwo w życiu społeczno-kulturalnym poszczególnych grup. Szczególnie istotne było odniesienie respondentów do społeczności międzynarodowej i kultury globalnej. Zmiana w autodefinicjach jednostki niesie za sobą konsekwencje dla jej biografii. Powstaje bowiem pytanie: czy możliwe jest zakończenie mobilności dla jednostki, która nie jest już „tą samą osobą", która wyjechała, ale która zaczyna postrzegać siebie jako osobę międzynarodową.

\section{Mobilność edukacyjna jako punkt wyjścia w karierze zawodowej}

Jednostki żyjąc w innych kulturach, spotykając osoby z innych krajów, żyjąc w społeczności międzynarodowej zmieniają sposób postrzegania siebie. Na nowo uporządkowują swój stosunek do kraju pochodzenia i osób, które w tym kraju pozostały. Wpływ kultury globalnej - międzynarodowej oraz kultury aktualnego miejsca pobytu (a było ich kilka) powoduje, że jednostka weryfikuje i zazwyczaj poszerza swoje definicje o wymiar międzynarodowy. Zmiana postrzegania siebie znacząco wpływa na ich dalsze decyzje. Takim kolejnym kluczowym momentem jest decyzja o powrocie do kraju.

Problem powrotu do Polski pojawił się w czasie moich badań samoistnie. Podczas pierwszych wywiadów respondenci, niezależnie od moich pytań, sami zaczynali mówić na ten temat. Głównym czynnikiem wpływającym na ich decyzję o powrocie lub pozostaniu za granicą jest kariera zawodowa. Stanowi ona najważniejszą wartość dla osób ze środowiska międzynarodowego. Praca wiążąca się z ciekawymi projektami i mobilnością jest dla nich wartością kluczową. Zatem, samej decyzji o powrocie nie należy łączyć bezpośrednio z identyfikacją narodową i uznaną za własną kulturą. Polityka państwa pochodzenia nie ma wpływu na ich poczucie przynależności narodowej, a jedynie na decyzję o powrocie do kraju, wraz z możliwościami dla ich kariery zawodowej. Brak perspektyw na rozwojową i ambitną pracę, problemy z polską administracją, a także niechęć ze strony pracodawców i społeczeństwa są głównymi czynnikami zniechęcającymi do powrotu osoby udzielające wywiadu. Również polityka prowadzona przez aktualne państwo pobytu ma pośredni wpływ na decyzję respon- 
dentów. Przede wszystkim, szansa pracy w skali światowej oraz system stypendiów wpływają korzystnie na ich wybór o pozostaniu.

Moi rozmówcy w większości nie dawali konkretnej odpowiedzi w kwestii powrotu do Polski. Decyzja ta nie jest dla nich łatwa i ulega wielokrotnie zmianie w czasie - zwłaszcza kiedy zbliża się wyznaczona przez nich data powrotu. Na przykład, Ania twierdzi, że zawsze podczas spotkań studenci rozmawiają o tym, czy decydują się na powrót czy nie, jednak "nikt nie wie", $\mathrm{i}$ „do ostatniego momentu ludzie powiedza, że nie wiedza". Wielu moich rozmówców wyjeżdżając za granicę zakładało po ukończeniu studiów powrót do Polski. Jednak obecnie ich plany uległy zmianie i kiedy otrzymają dyplom ukończenia studiów zamiast wrócić do Polski, zamierzają podjąć na przykład kolejne studia. Takie plany ma Grzegorz, który stwierdził: „(...) ten powrót do Polski się oddala, tym bardziej że bardzo chciałbym spróbować aplikować do Oksfordu albo do Cambridge". Z kolei Ola rozważa aplikowanie na studia doktoranckie. Inne osoby planują podjąć za granicą kilkuletnią pracę zawodową $\mathrm{w}$ celu zdobycia przydatnego doświadczenia, które $\mathrm{w}$ ich opinii będzie atutem, kiedy będą aplikować o pracę w Polsce (Piotrek, Ola). Piotrek planuje, że: „po skończeniu studiów 3 lata pracować gdzieś w pracy normalnej, a dopiero potem wracać do Polski. W takim razie 3 lata albo w Anglii, albo gdzie bym taka prace dostał gdzieś za granica, zdobyć to doświadczenie zawodowe i wrócić do Polski, chyba że pójdę w astronomię". Wydaje się jednak, że zmiana planów i przedłużanie pobytu za granicą należy wiązać z obawą przed podjęciem decyzji o powrocie. Na przykład Grzegorz mówi, że być może sam się „oszukuje”, że wróci. Respondenci zdają sobie bowiem sprawę, że im dłużej będą tę decyzję odkładać, tym trudniej będzie im wrócić do Polski (Julia, Ola). Trudno właściwie stwierdzić, czy kiedykolwiek podejmą ostateczną decyzję. Wielu studentów w momencie przeprowadzania wywiadów nie potrafiło opowiedzieć o swoich planach: "Ale co później to się okaże tak naprawdę i czas pokaże"; "tak ciagnie, tak do tego, żeby gdzieś kiedyś wrócić, ale zobaczymy. No coraz bardziej świat się mobilny robi, staje, prawda? Więc, więc można dzielić życie między tu i tam, można częściej jeździć, można, różne rzeczy można" (Jagoda); "(...) czy kiedyś wrócę to nie wiem, zobaczymy jak to tam wyjdzie wszystko" (Łukasz); "Trudno powiedzieć w tym momencie” (Magda); „(...) nie to żebym chciała w tym momencie wracać natychmiast, ale gdzieś jest ta myśl, że nie wiem, że może za 5-8-10 lat znudzi mi się to wszystko zatęsknie za pierogami" (Monika). Nie wszyscy jednak mają tego rodzaju dylematy. Niektórzy moi rozmówcy twierdzą, że nie planują powrotu do kraju (Elżbieta, Bartek, Jerzy, Asia): „(...) nie buduje planów jakiś opartych na tym, że kiedyś wrócę do Pol- 
ski, bo może kiedyś wróce, nie wiem, nie zarzekam się, ale z drugiej strony nie widze perspektyw" (Asia).

Analizując wypowiedzi moich rozmówców, wyłania się kilka przyczyn wątpliwości lub niechęci związanych z powrotem do Polski. Przede wszystkim, studenci są przekonani, że nie będą mieli możliwości podjęcia ciekawej pracy, odpowiadającej posiadanym kwalifikacjom i doświadczeniu. Częstym powodem niechęci powrotu do kraju pochodzenia jest także obawa przed nepotyzmem w Polsce i brakiem możliwości otrzymania pracy bez odpowiednich koneksji. Kolejnym powodem jest obawa, że polscy pracodawcy nie będą chcieli ich zatrudnić, ponieważ ukończyli studia $w$ innym kraju. W wywiadach studenci wskazywali także inne powody trudności znalezienia pracy w Polsce i niechęci ze strony polskich firm. Przyczyną tego są zbyt wysokie kwalifikacje względem oczekiwań pracodawców na aplikowane stanowiska. Ponadto, moi rozmówcy dostrzegają jeszcze jeden aspekt trudności związany z szukaniem pracy w Polsce, który jest związany $\mathrm{z}$ brakiem ich wiedzy o polskim rynku pracy. Studenci nie znają systemu aplikowania o pracę oraz nie mają sieci kontaktów zawodowych. Nie mają wiedzy i umiejętności osób dorosłych, jakie posiadają ich rówieśnicy, którzy pozostali w kraju. Dla moich rozmówców socjalizacja w Polsce zakończyła się zazwyczaj wraz z ukończeniem szkoły średniej. W sytuacji powrotu odczuwaliby duży dyskomfort związany z readaptacją do życia w kraju i koniecznością uzupełnienia brakujących umiejętności związanych z codziennym życiem w Polsce.

Żaden mój rozmówca nie podjął jednoznacznej decyzji o powrocie i mimo wewnętrznego rozchwiania nie wydaje się, aby taką decyzję mieli podjąć. U większości z nich jest to długotrwały proces, często wyznaczany przez termin zakończenia studiów. Należy zaznaczyć, że w przypadku osób, które już pojęły decyzję o niewracaniu do Polski po ukończeniu studiów, czas nauki na uniwersytecie stanowi specyficzny etap w życiu człowieka. Charakteryzuje się on - niezależnie od miejsca - zwiększoną liczbą kontaktów z osobami pochodzącymi z różnych środowisk. Brak zobowiązań rodzinnych i zawodowych ułatwia swobodną zmianę pobytu. Ponadto, szeroka oferta stypendiów i staży uławia podróż, bez obaw o środki utrzymania. Trudno przewidzieć, czy decyzja studentów nie ulegnie zmianie kiedy ukończą edukację na uniwersytecie i wejdą na rynek pracy. Z kolei, ci moi rozmówcy, którzy wspomnieli o możliwości powrotu do kraju nie traktowali go w kategoriach porażki, ale jako pewnego rodzaju „asekuracyjną" drogę, która nigdy nie jest zamknięta. Dla nich powrót do Polski, pomimo licznych 
wątpliwości, jest zawsze możliwy. A jest on możliwy, ponieważ ich autodefinicje związane $\mathrm{z}$ identyfikacją narodową i uczestnictwem $\mathrm{w}$ kulturze, pomimo zmian, pozostają ciągle ważnym aspektem ich tożsamości.

\section{Zakończenie}

Osoby skupione $\mathrm{w}$ studenckim środowisku międzynarodowym poprzez mobilny styl życia wyrażają nowe właściwości procesów migracyjnych i stanowią szczególną zbiorowość wśród innych emigrantów. Studenci nie wyjeżdżają z kraju z powodu braku zatrudnienia i trudnej sytuacji ekonomicznej, nie podejmują pracy poniżej swoich kwalifikacji i nie korzystają z zasiłków socjalnych dla osób bezrobotnych, posługują się bardzo dobrze językiem obcym, $\mathrm{z}$ własnej woli często zmieniają miejsce pobytu $\mathrm{w}$ celu zdobycia kolejnych doświadczeń życia $w$ innych miejscach i krajach. Inni uczestniczą w krótkotrwałych wyjazdach w odmienne miejsca $\mathrm{w}$ celu poszerzenia swojego dorobku naukowego lub uzyskania doświadczenia zawodowego. Mają także plany dalszego podróżowania - krótko- lub długoterminowego. Przebywają w środowisku akademickim, które samo w sobie jest międzynarodowe. $\mathrm{Z}$ drugiej jednak strony, polscy studenci charakteryzują się typowymi cechami emigrantów. Przede wszystkim, pozostają ciągle członkami wspólnoty narodowej i mimo że korzystają ze swobody przemieszczania się, jaką daje Unia Europejska, nie zmienia to faktu, że również oni - jak pozostała część poakcesyjnej emigracji - doświadczają problemów związanych $\mathrm{z}$ adaptacją do nowego środowiska. Wiąże się to z koniecznością uporządkowania dotychczasowych autodefinicji z nowymi określeniami samego siebie, które pojawiają się wraz z kolejnymi doświadczeniami oraz obecnością osób pochodzących z różnych krajów. Mobilność edukacyjna jest zatem punktem zwrotnym $\mathrm{w}$ życiu jednostki w obszarze jej tożsamości. Zmiana postrzegania samego siebie wpływa z kolei na dalsze życie jednostki, która może pozostać mobilną, osiedlić się za granicą lub wrócić do kraju. Jednakże, ich wybór nie ogranicza się jedynie do tych trzech możliwości. Współczesny świat oferuje bowiem znacznie więcej możliwości - powrót do kraju może okazać się krótkotrwałym pobytem, osiedlenie się za granicą za kilka lat może okazać się jedynie dłuższym przystankiem w podróży. Decyzja o mobilności stanowi znaczący punkt w biografii jednostki, jednak jej dalszy przebieg naznaczony jest niestałością i tymczasowością. 


\section{BIBLIOGRAFIA}

Appadurai A., Nowoczesność bez granic. Kulturowe wymiary globalizacji, Towarzystwo Autorów i Wydawców Prac Naukowych Universitas, Kraków 2005.

Babiński G., Polonia w USA na tle przemian amerykańskiej etniczności, Krakowskie Towarzystwo Edukacyjne, Oficyna Wydawnicza AFM, Kraków 2009.

Budakowska E., Wspótczesne migracje a nowe wyzwania wobec identyfikacji narodowokulturowej, [w:] Tożsamość bez granic. Wspótczesne wyzwania, red. E. Budakowska, Wydawnictwo Uniwersytetu Warszawskiego, Warszawa 2005.

Castles S., Miller M.J., Migracje we współczesnym świecie, przekł. A. Gąsior-Niemiec, Wydawnictwo Naukowe PWN, Warszawa 2011.

Grzymała-Kazłowska A., Ku socjologii mobilnego społeczeństwa? Rozwój nowych koncepcji migracji i integracji a socjologia, Studia Socjologiczne, 2013, 3(210).

Kaczmarczyk P., Okólski M., Migracje specjalistów wysokiej klasy w kontekście członkostwa Polski w Unii Europejskiej, Urząd Komitetu Integracji Europejskiej, Departament Analiz i Strategii: współpr. Departament Dokumentacji Europejskiej i Publikacji, Warszawa 2005.

Kaźmierska K., Wywiad narracyjny jako jedna z metod w badaniach biograficznych, Przegląd Socjologiczny, 2004, LIII/1.

Niedźwiedzki D., Migracje $i$ tożsamość. Od teorii do analizy przypadku, Zakład Wydawniczy Nomos, Kraków 2010.

Ośrodek Badań nad Migracjami, „Biuletyn Migracyjny”, 2010, 26 http://biuletyn migracyjny.uw.edu.pl/pliki/pdf/biuletynmigracyjny26.pdf , [dostęp: 9.04.2013].

Reimann G., Schütze F., "Trajektoria” jako podstawowa koncepcja teoretyczna w analizach cierpienia i bezładnych procesów społecznych, Kultura i Społeczeństwo, 1992, 2, XXXVI.

Rokuszewska-Pawełek A., Chaos i przymus. Trajektorie wojenne Polaków - analiza biograficzna, Wydawnictwo Uniwersytetu Łódzkiego, Łódź 2002.

Romaniszyn K., Kulturowe implikacje międzynarodowych migracji, Instytut Badań nad Polonią i Duszpasterstwem Polonijnym KUL, Lublin 2003.

Urry J., Socjologia mobilności, Wydawnictwo Naukowe PWN, Warszawa 2009.

UK Council for International Student Affairs (UKCISA), http://www.ukcisa.org.uk/ about/statistics_he.php,[dostep:9.04.2013]. 